\title{
Some Reflections on the
}

\section{Prospects for the Harmonization of}

International Business Laws in Africa: OHADA and Beyond

\section{Charles Manga Fombad}

The evidence of developments in the harmonization of international business laws shows that Africa is lagging seriously behind. There are still some skeptical voices about the need for and the value of harmonization of international business laws, but such voices are now in a minority. The aim of this paper is to assess the prospects for harmonizing international business laws in Africa. The main contention is that the debate today in Africa is not whether or not there should be harmonization of international business laws, but how this should be done. The paper reviews the imperatives for harmonization and the options that exist and then focuses on the present approach to harmonizing business laws in Africa under the auspices of the Organization for the Harmonization of Business Laws in Africa, better known under its French acronym, OHADA. Based on the critical review of the weaknesses and strengths of the OHADA regulatory framework, the paper suggests ways in which the agenda to develop a harmonized and modern set of business laws in Africa can be achieved.

Globalization, regionalization, and liberalization have seen the emergence of a global economy and intensified the need for strong linkages and interconnections among states, regions, and societies. Africa has not been able to reap fully the benefits of these developments, despite the abundance of its natural and human resources. Foreign investment and intra-African trade have stagnated, ${ }^{1}$ largely because of the legal and judicial uncertainty caused by the existence of a diversity of legal systems, many of which are based on antiquated and often contradictory laws inherited from the colonial period. The archaic legal framework in most countries has been prejudicial to the establishment and growth of businesses and is accentuated in many instances by rampant corruption and inefficiency of the judiciary. 
African countries have now realized that an important step in dealing with the economic crisis that has almost destroyed their economies, overcoming challenges of globalization, and unlocking the continent's growth potential is to remove the legal impediments to international trade, particularly intra-African trade. This realization has led to attempts to modernize the legal framework by harmonizing business laws on the continent. An overview of developments in the process of harmonizing international business laws on the different continents shows that Africa is lagging seriously behind. ${ }^{2}$ It is an irony that while Africa has made tremendous strides in regional integration, the legal measures that are crucial to cementing economic and political integration have by and large not figured prominently on the agenda. There are still some skeptical voices about the need for and the value of harmonization of international commercial law, but such voices are now in a minority. ${ }^{3}$ The main contention in this paper is that the debate today in Africa is not whether or not there should be harmonization of international business laws, ${ }^{4}$ but how this should be done.

The next section of the paper sets the framework of the discussion by examining the concept of harmonization. This is followed by a discussion of imperatives and challenges in the process of harmonizing business laws on the continent. Available options for harmonization are discussed before a critical review of the only legal framework for the harmonization of business laws in Africa provided for under the Organization for the Harmonization of Business Laws in Africa, better known by its French acronym, OHADA, ${ }^{5}$ is discussed. This is followed by a consideration of the way forward and concluding remarks. It is contended that any meaningful and successful harmonization of business laws in Africa must not only take the past into account, but be conscious and sensitive to past, present, and future legal, social, political, and economic realities. It is therefore suggested that what is needed to promote the harmonization of business laws in Africa is a new, diversity-conscious approach, one that ensures the formulation of rules that are clear, flexible, modern, and fair. OHADA will need to change its modus operandi dramatically to achieve this, and the African Union needs to set up a commission of legal experts with a broad mandate to initiate the harmonization of international business laws in Africa.

\section{The Concept of Harmonization}

The concept of harmonization is not new and appears quite frequently in the literature, but its exact meaning is not always clear. As a result, one is not always certain what the objective is. Is it synonymous with the unification of laws? Does it imply that harmonized laws must be uniform? This difficulty is usually acute on the African continent, where diverse legal systems operate within some countries. A typical example of this is Cameroon, which supposedly has a bijural system, but where harmonization has become 
a means for unifying the law in a manner that eliminates inconvenient historical legal differences. ${ }^{6}$

One of the best attempts to clarify the concept of harmonization is that of Martin Boodman in his paper "The Myth of Harmonization of Laws" (1991). ${ }^{7}$ As he rightly points out, a crucial attribute of harmonization is that it presupposes and preserves the diversity of the objects harmonized. Using the analogy of music, he points out that harmony requires diversity and eschews uniformity: the harmonization of laws therefore does not mean that all differences should be eliminated. ${ }^{8}$ Instead, it is a process in which the elements of different legal systems are combined or adapted to each other so as to form a coherent whole while retaining their individuality. ${ }^{9}$ Another writer has described it as a process in which a type of transaction in one legal system is brought as close as possible to a similar transaction under the laws of other countries. ${ }^{10}$ The process may therefore require legislative complementarity, not legislative similarity. ${ }^{11}$

Harmonization must be seen as a process whose exact outcome cannot be predetermined: its nature and level will depend on the particular problem to be solved and the legal elements implied in it. Sometimes, it may mean nothing more than a process in which differing laws are made easier to understand or comply with, but sometimes it may entail more profound changes, resulting in the introduction of new concepts and principles from another system. As a mechanism to solve problems, harmonization in this context must be considered as indefinite in its configurations as it is the legal problems that it can solve. ${ }^{12}$ This probably explains why some authors want to distinguish among slight, moderate, and comprehensive harmonization and make other distinctions, such as total or complete, minimum, and optional harmonization. ${ }^{13}$ Even the United Nations Commission on International Trade Law (UNCITRAL), from an analysis of its approach to the harmonization of international trade law, appears to have adopted what can be seen as a flexible approach, combining what some have called hard and soft definitions of harmonization. ${ }^{14}$ The hard definition views the concept as involving the convergence of nonuniform national laws around an agreed international standard, with the ultimate goal being unification over time; the soft definition views harmonization as a process of reduction of differences over time. ${ }^{15}$

From the literature on the topic and the practice of many agencies involved in the harmonization of international business law, the concept can be said to involve a broad and flexible process, designed to modernize the law in a manner that will reduce or, where possible and desirable, eliminate differences in national laws. If this is the goal, then before one examines the attempts to achieve it in Africa, one must consider the imperatives for this process and the challenges that exist to achieving it. 


\section{Imperatives for and Challenges to the Harmonization of International Business Laws in Africa}

Two main issues are addressed in this section: first, what imperatives exist for harmonizing business laws in Africa; second, what challenges need to be overcome to achieve this purpose.

\section{Imperatives for Harmonizing International Business Laws in Africa}

Most African publications on international business laws underscore the need for legal harmonization of the national laws in this area. ${ }^{16}$ The fact that in spite of this, and apart from the efforts by OHADA, so few steps have been taken to accomplish this is a surprise, mainly because in the last decade, Africa, particularly since the establishment of the African Union in 2002 and several Regional Economic Communities (RECs), has shown a strong commitment toward removing the economic, social, and political obstacles that have impeded the continent's development, but in doing so, it has not done enough to remove the legal barriers that continue to impede economic integration. As noted earlier, Africa is the continent where the least progress has been made in harmonizing international commercial law. Several reasons make it more imperative today than in the past for the project of harmonizing international business law to be firmly put on the agenda of priority developments in the next few years. These can be summarized under three points: the legal argument, the economic argument, and the political argument.

The legal argument for harmonization is based on the fact that the legal framework regulating business laws in African countries is not only diverse in a manner that poses huge legal obstacles to intra-African trade, but is still largely based on now largely obsolete laws that were received during the colonial period. The antiquity of these laws is often compounded by uncertainty over their exact content or scope of application. ${ }^{17}$ In anglophone Africa, it is not unusual to find courts relying on outdated English statutes. For example, in the anglophone regions of Cameroon, old English statutes such as the Factors Act of 1882, the Sale of Goods Act of 1893, and the Partnership Act of 1890, long repealed in England, were until the introduction of the OHADA regime in the 1990s the law regulating business transactions. Even in the francophone regions of Cameroon and francophone countries in general, there was still continuous reliance on the French Civil Code of 1804 and on the Commercial Code of 1807 long after it had been repealed. ${ }^{18}$ Besides being outdated, the business laws were often hard to access. Their uncertainty and unpredictability were compounded by the lack of access to sources of legal information, such as modern textbooks, case reports, statute books, and gazettes. In many countries, particularly in rural areas, there are no libraries, or those that exist have been neglected for years. Many African countries have no regular and reliable system of law reporting. The core of the legal argument is therefore that harmonizing business laws will 
provide an opportunity not only to introduce uniform laws applicable to African countries, but to modernize the laws and create legal certainty and predictability.

The crux of the economic argument is that the harmonization of business laws will reduce the costs of doing business, which are increased by the diversity in legal rules in the different countries. It is widely acknowledged that increased trade among African countries themselves is the key to unlocking the continent's economic growth potential. According to Jeremy Stevens, only about 10 percent of African trade is within the continent, and this is the lowest level in the world. ${ }^{19}$ In comparison, 40 percent of trade in North America is within the region, while intraregional trade in Europe stands at 60 percent. ${ }^{20}$ Intra-African trade has remained low despite trade reforms, better macroeconomic management, investments in infrastructure, and more constructive trade partnerships. Africa has eight RECs officially recognized by the African Union, ${ }^{21}$ and the enthusiasm of African governments for regional integration is reflected in the large number of regional integration agreements that have been concluded, as well as the ongoing discussions to create a free trade zone that would stretch the length of the continent, merging three existing trade blocs in eastern, central, and southern Africa. ${ }^{22}$ Despite these serious steps toward integrating the economies on the continent, a critical factor in breaking down barriers to intra-African trade-an enabling legal environment—has hardly been given serious attention. As has been noted by several commentators, if a trader in one African country, for example, Cameroon (where the civil-law system predominantly applies), tries to do business with another, say from Nigeria (where the common-law system applies), innumerable legal obstacles may have to be overcome. ${ }^{23}$ The parties will have to overcome the problem of legal diversity by relying on the rules of private international law to decide the country whose laws will apply if there is a dispute. This is so, regardless of how simple or complicated the transaction may be, nor will it matter that the transaction is between parties from the same ethnic group who are separated by a border imposed during the colonial period. The extra costs involved in complying with the law of a jurisdiction that is within a few kilometers of the trader and offers only a small market might well discourage any entry into that market. Considering the low level of intra-African trade and the need for expanding this trade to enable the economies to recover from the economic crisis that has crippled the continent for longer than a decade, it is clear that the costs of disharmony of the laws are significant enough to be a factor in arguing that the harmonization of business laws is the missing link needed to cement efforts at economic integration.

The third argument, the political one, reinforces the other two. In the globalized and regionalized world of today, Africa is the weakest, not only politically, but also economically. The establishment of the African Union in 2002 has done much to bring the continent together to speak to the rest of the world with one voice. If business laws in Africa were harmonized, it would be easier for the continent to deal with the rest of the world as a unit, 
and foreign partners would no longer be able to play one country against another and exploit differences in legal regulations and regimes to underpay for the goods and services they obtain. Considering that the reasons for the continuous divergence of legal systems reflect the existence of sovereign political entities, the considerable progress made in intensifying political unity among African countries would experience extra momentum from concerted efforts to harmonize some aspects of the diverse legal systems, the most urgent of which obviously involve international business laws among African states. Before we examine what options exist, it is necessary to consider obstacles that must be taken into account before any serious continentwide initiative to harmonize business laws is attempted.

\section{Challenges to Harmonizing International Business Laws in Africa}

Several factors make the harmonization of international commercial laws in Africa a delicate and challenging exercise, which needs to be pursued with caution and sensitivity. A major problem, alluded to above, is the diversity of legal regimes on the continent. These include the civil-law system in francophone, lusophone, and hispanophone Africa, the common-law systems in anglophone Africa, the bijural system in Cameroon (a combination of English and French law), and the hybrid (consisting of Roman-Dutch and English law) in southern African countries such as Botswana, Namibia, Lesotho, Swaziland, South Africa, and Zimbabwe. Within some African countries, Islamic law plays either an important role, as in the arabophone countries, or a limited role, as in parts of Nigeria, Cameroon, Niger, and Mauritania. African customary law plays a limited role in some African countries. Any harmonization of laws must take this legal diversity into account, particularly the three legal systems_English, civil-law, hybrid-inherited from the colonial period.

There is still considerable reliance on the laws inherited at independence (whether from France, Portugal, Spain, or Britain), but the laws in some fields, such as business, have hardly been revised to take account of the economic, political, and social changes that have occurred since the 1960s. This has been so despite some fairly radical legal reforms in the European countries from which these laws had originally come. In many countries, this has been due to the absence of an efficient mechanism or clear strategy for initiating legal reforms, especially on complex and sophisticated matters such as business laws. Any attempts at harmonization would therefore account for not only the potential diverse sources, but also the fact that even for those who share a common historical source of reception, some might be up to date while others might have retained the laws in the form they had been received. ${ }^{24}$

Another problem is that of conservatism. In Europe, the European Union has in many respects provided a platform for reconciling the differences between the common law and the civil law, but in Africa, neither the 
African Union nor the RECs have done much to bridge the gap that has kept francophone and anglophone jurists apart. No country illustrates the complexities and difficulties in reconciling these main legal cultures better than Cameroon. ${ }^{25}$ There will hardly be any incentive to suggest legal harmonization among the legal systems in Africa if there is so little knowledge of them. It is ironic that in the law programs in African universities, hardly any place is reserved for a comparative study of African legal systems. Such ignorance provides fertile ground for suspicion, prejudice, and distrust to take root, and it is particularly acute among academics who fear the unknown. Even today, when African legal academics from different legal systems meet, their tendency is to defend and protect what they know and make little space to learn what other legal systems have to offer. This tendency is exacerbated by obsessive, extensive, and uncritical reliance on the inherited legal systems.

Another challenge arises from language differences, ${ }^{26}$ which are particularly problematic because legal concepts and terminologies in one language often have no exact equivalent in another. There is no better proof of this difficulty than the attempts by OHADA to translate the founding treaty and some of its uniform acts into English. ${ }^{27}$ It is a commendable attempt, but quite often the translation is so literary that the text is hard to comprehend.

Differences in the pace and level of legal, political, social, and economic development inevitably affect the attitude and approach a country will adopt toward legal harmonization. Reaching agreement on harmonization among states that include fully fledged democracies, dictatorial states, Islamic states, and failed states will not be easy, nor will some of the major players on the scene, such as South Africa, Nigeria, and Egypt, resist the temptation to impose on the smaller states and influence the harmonization process.

The absence of any specialized institutional arrangements within the African Union or the RECs to coordinate and facilitate the harmonization of commercial laws on the continent is a problem that cannot be lightly ignored. The African Union, as Africa's premier institution and principal organization for promoting socioeconomic integration and economic development, should have taken the lead and followed up on its establishment of the African Union Commission on International Law (AUCIL), primarily concerned with strengthening and consolidating common approaches to international legal development, with a similar body to deal with issues of legal harmonization of laws on the continent.

Finally, the weak, unreliable, inefficient, and often corrupt court systems in Africa will make the uniform interpretation and enforcement of harmonized laws across legal boundaries on the continent a big challenge. Be that as it may, the harmonization of international commercial law in Africa is not only necessary but imperative. The critical question, however, is to determine how best this can be achieved. The obvious starting point is to review the attempts on harmonization of international commercial law elsewhere to see what lessons can be learned. 


\section{Diverse Approaches to Harmonizing International Business Laws}

Before critically reviewing the approach that OHADA has adopted in harmonizing international commercial law in Africa, it is necessary to consider the approaches that have been adopted globally in attaining this goal. Two main issues are considered here: first, the agencies that have initiated the process; second, the main forms in which the harmonization has been carried out.

\section{The Main Agencies of the Harmonization Process}

The main active agencies in the international harmonization of business law in the world can be put into two main categories: institutional initiatives that have come through public or governmental international organizations and those that have come from private or nongovernmental organizations. The latter category includes efforts of multinational business enterprises.

Initiatives by Public or Governmental International Organizations The main objective of the United Nations is the maintenance of international peace and security. ${ }^{28}$ Nevertheless, right from the beginning, the drafters of the UN Charter recognized that one of the best ways to keep the peace was to promote economic growth and prosperity. It is therefore unsurprising that the United Nations over the years has shown strong support for initiatives that aim to promote world trade. One of the ways it has done this is through supporting projects on the harmonization of international business laws.

Several UN-affiliated organizations are working on harmonizing international business laws, but by far the most important and influential is the United Nations Commission on International Trade Law (UNCITRAL), established in 1960, when world trade had begun to expand quite dramatically and national governments had recognized the need for a global set of standards and rules to harmonize and modernize the assortment of national and regional regulations. UNCITRAL has become the core legal body of the UN system in the field of international trade law. ${ }^{29}$ Its aim is to remove or reduce legal obstacles to the flow of international trade and progressively modernize and harmonize trade laws. It tries to coordinate the work of other organizations involved in harmonizing business laws. The UN resolution that created UNCITRAL spoke of "progressive harmonization and unification" 30 of the law of international trade, but recently the mission has been defined as the "modernization and harmonization" of trade law, reflecting the sense in which the concept of harmonization is now being used. Three main points about UNCITRAL need to be noted here.

First, UNCITRAL has moved away from its initial and traditional focus on the unification of laws to reflect the fact that in some areas, governments are interested more in legal modernization than unification. Second, it uses five types of texts for different purposes: conventions, model laws, legislative guides, contractual rules, and legal guides. ${ }^{31}$ The meaning of the 
first two is discussed below. For the others, legislative guides are texts that provide guidance for the development of laws, discussing relevant policy issues and choices and recommending appropriate legislative solutions. Contractual rules provide standard clauses or rules designed to be included in commercial contracts. Legal guides are texts that provide guidance for the drafting of contracts, discussing relevant issues, and recommending solutions appropriate to particular circumstances. These shifts in emphasis according to the subject matter suggest that differences in legal systems are not the main problem in international trade. The third point to note is that over the last forty-six years, UNCITRAL has produced a large volume of international texts on the sale of goods, transport, dispute resolution, procurement, infrastructure development, international payments, electronic commerce, insolvency, and international arbitration. One of the most significant of these documents is the United Nations Convention on Contracts for the International Sale of Goods (CISG) 1980..$^{32}$ UNCITRAL texts have been widely adopted and play an important part in facilitating international trade, especially the CISG, today regarded as one of the most harmonizing trade instruments. What is immediately striking is that UNCITRAL has adopted a flexible approach to harmonization and uses any of five methods, depending on the subject matter of the process.

Another UN-associated body that has been involved in the harmonization of international trade law is the United Nations Conference on Trade and Development (UNCTAD), the first of which was held in Geneva in $1964 .{ }^{33}$ Born out of growing concerns about the place of developing countries in international trade, UNCTAD was institutionalized to meet every four years. ${ }^{34}$ Some problem areas of trade have been dealt with by it. Although harmonization of international trade law is not its principal focus, it has elaborated numerous texts, such as the United Nations Multimodal Transport Convention of 1980, and set up model rules for multimodal container tariffs, which could be used in establishing the terms and conditions of multimodal transport containers. In recent years, its focus has been on activities in international investment agreements. Some international agencies associated with the United Nations_-such as the World Intellectual Property Organization, the United Nations Educational and Scientific Organization, the United Nations Industrial Organization, and especially the International Labor Organization - in the course of their activities usually prepare and recommend to member states uniform standards and rules based on best practices.

Two other independent intergovernmental organizations that predate the United Nations have been active in promoting legal harmonization. The older, the Hague Conference on Private International Law, was first convened in $1893 .{ }^{35}$ Since the adoption of its statute in 1955, it has become a permanent intergovernmental organization, which meets every four years. Its main purpose, according to article one of its statute, is "to work for the progressive unification of the rules of private international law." It negotiates and drafts multilateral treaties or conventions in private international 
law, such as conflict of laws for contracts, torts, maintenance obligations, the status and protection of children, the recognition of companies and jurisdiction, and the enforcement of foreign judgments. It has adopted more than forty international conventions, and among those that have been widely ratified are the conventions on civil procedure, the service of process, the taking of evidence abroad, the recognition of divorces, the protection of minors, and legalization.

The other intergovernmental organization is the International Institute for the Unification of Private Law (UNIDROIT), set up in 1926 with its seat in Rome. ${ }^{36}$ Its purpose is to study the needs and methods of modernizing, harmonizing, and coordinating private and in particular commercial law between states and groups of states and to formulate uniform law instruments, principles, and rules to achieve these objectives. It has prepared more than seventy studies and draft international instruments, including international conventions and model laws. Examples of these are the Convention Relating to a Uniform Law on the Formation of Contracts for the International Sale of Goods of 1964, the Convention on Agency in the International Sale of Goods of 1983, the Model Law on Leasing of 2008, and the Convention on Substantive Rules for Intermediated Securities of 2009.

Though UNCITRAL, UNCTAD, the Hague Conference, and UNIDROIT are harmonization agencies with global membership, other public agencies-some linked to the United Nations, but with far more limited membership - are involved in similar activities. Within the UN system, the different regional economic commissions, such as the Economic Commission for Africa, often engage in programs that try to harmonize certain aspects of international trade law within their regions. But while the European Union, the Organization of American States, the Association of Southeast Asian Nations, and other regional organizations have been involved in facilitating trade in their regions through the harmonization of trade laws, little of this had happened under the auspices of the African Union or the various RECs in Africa. ${ }^{37}$ Apart from the efforts of these public intergovernmental organizations to overcome the problems caused by the diversity of national laws, there have been attempts by private organizations.

Initiatives by Private or Nongovernmental Organizations Several organizations have been active in formulating uniform rules to facilitate international trade. Some of these rules, in the form of codes, are developed by industry organizations such as the International Chamber of Commerce, and individual commercial parties may decide to adopt them by referring to them or incorporating them in their agreements. The International Chamber of Commerce's Incoterms and Uniform Customs and Procedures for Documentary Credits are good examples of such codes. These are open for voluntary acceptance, but market pressures may leave parties in a particular market with little choice than to adopt them. The role of private agencies in formulating harmonized legal regimes for international trade is increasing with the expanding reach of globalization, but unlike public agencies, which 
promote the interest of the wider public, these agencies act to further their own interests and only incidentally promote harmonization. Learned institutions with an interest in contributing to the harmonization process must be included under private bodies. An example is the African Law Institute, which, in cooperation with the Commercial Law for Development Program of the US government, prepared and adopted in December 2003 a model, tenarticle law on investment in Africa designed to help improve the legal incentives for investment in sub-Saharan Africa. This law incorporates principles of civil and common law and best practices in international investment.

\section{The Main Methods of Harmonization}

Two main means have traditionally been used as the vehicles ${ }^{38}$ of the harmonization of laws: formal, legally binding instruments and soft laws. These will now be briefly considered.

\section{The Use of Formal Legal Instruments: International Treaties and Conven-}

tions The first and perhaps most obvious method of promoting the harmonization of international business laws generally is through concluding legally binding instruments in the form of treaties or conventions, instruments that have the advantage that once they are ratified by governments, they become binding, though they still have to be domesticated by the signatory states. If a high number of countries ratifies or accedes to such conventions, a reasonably high degree of harmonization can be achieved. To make harmonization by way of binding instruments more attractive and allow for differences resulting from the diversity of legal systems, reservations on certain issues can be allowed, the only disadvantage of which is that it carries the risk of limiting the extent of uniformity.

What are the prospects that such treaties and conventions will be used to harmonize business laws in Africa? Many African countries have had no problems ratifying or acceding to international conventions in harmonizing international business laws, whether in the context of the World Trade Organization or UNCITRAL. There is thus no reason why they should not become parties to a regional convention specifically designed to take account of their needs and priorities, provided, of course, that it is well drafted. It may be that because many of these countries are already parties to these global international business-law instruments, harmonization at the regional level should not be too complicated. The fear has been expressed that differences in the interpretation of such harmonized instruments in the national system may compromise its uniformity, but experience with the interpretation of the CISG suggests that a great deal of consistency has been achieved because the courts refer not only to the legislative history of the convention and its provisions, but to other domestic decisions and writings, as well as international decisions and literature.

It would appear that, from the perspective of harmonization of international business laws through regional treaties and conventions, the best 
way forward would be for the mandate of the newly established AUCIL to be expanded or another specialized body created that will be given the powers to identify priority areas in substantive and procedural law where harmonization is absolutely essential to enhancing inter- and intraregional trade.

The Use of Soft Law At the present stage of the development of international business laws in Africa, it can be argued that soft law has a considerable role to play. In fact, it has even been suggested that soft law constitutes the most significant means for the harmonization of laws. ${ }^{39}$ Soft law may take many forms: it may refer to many instruments, such as declarations and communiqués, that result from intergovernmental conferences or meetings or resolutions of the African Union Assembly or any of its principal organs. It includes guidelines or recommendations made by an international organization or codes of conduct prepared by private intergovernmental or nongovernmental organizations.

A number of important features of soft law must be noted. ${ }^{40}$ First, the main feature of soft law is that it is not binding. This may be because it is vague and does not establish precise rules of conduct or merely provides general principles or programs envisaging goals to be achieved without laying down concrete rights and obligations. The form in which it appears does not matter; for example, a treaty that lays down no binding obligation is soft law. Its nonbinding nature has two advantages: it may facilitate the conclusion of an agreement because noncompliance with its terms is not as serious as the consequences of noncompliance with a treaty, and it can be rapidly adopted without going through the complex and often protracted processes of domestication; this has the advantage that it can be rapidly modified as the need arises. Unlike other forms of international legislation, soft law covers a much wider sphere of application because it is not exclusively or even primarily addressed to states and international organizations but applies to natural and legal persons. ${ }^{41}$ Soft law cannot automatically be regarded as customary international law, though it may become a source of customary international law; nevertheless, it is significant because it reflects the necessity of regulation, states' intentions, and international consensus. In this regard, it may be considered a form of evidence of state practice and opinio juris. It creates such a sense of expectation among the parties involved in its formulation that its provisions will be respected; as a result, it may have an effect on national legislation because legislators may use it as a reference point for modernizing legislation.

The question here, then, is whether soft law thus defined can help promote the process of harmonization of international business laws in Africa. It is emerging in several ways as a vehicle for harmonizing international commercial law in Africa.

The most significant form of this is by way of model laws or codes that can be prepared within the framework of the African Union or by a private organization. These model laws or codes provide a standard harmonized text 
in a particular area that can be adapted or modified by individual countries and made part of their domestic law. The best example of the extensive and reasonably successful use of model laws as a means of harmonization of international business laws at the international level is UNCITRAL. ${ }^{42}$ The African Union has used the model-law approach in harmonizing the law in various areas, ${ }^{43}$ and one would expect that with the establishment of the AUCIL many more such model laws will be prepared in the future. As noted earlier, all private organizations that have taken initiatives in making international business laws have done so through soft laws. The advantage of using model laws or codes in the harmonization process is that they provide a flexible approach, allowing states to adapt and adjust the model to suit the peculiarities of their legal system. This flexibility, however, is its major weakness: there is no guarantee of harmonization and consistency because of the changes that states may introduce.

Besides model laws and rules, other forms of soft law from the practice of UNCITRAL are legal and legislative guides and recommendations. The flexibility that soft laws take allows for complementary legislative activity at the national level. Soft law in many respects reflects an adaptation to the legal reality of the "new international order."44

Having examined the different approaches and vehicles adopted in the world to finding common grounds in regulating international business law, we now take a critical look at the OHADA approach and see what prospects it offers for harmonization in Africa.

\section{A Critical Appraisal of the OHADA Approach}

This section briefly provides an overview of OHADA and then critically reviews the approach it has adopted toward harmonizing business laws in Africa.

\section{An Overview of OHADA}

The Organization for the Harmonization of Business Law in Africa (OHADA), was created on 17 October 1993 in Port Louis, Mauritius. ${ }^{45}$ It is made up of seventeen mostly francophone countries in west and central Africa and includes the Comoros (outside the region), Guinea Bissau (lusophone), Equatorial Guinea (hispanophone), and Cameroon (with an anglophone minority). ${ }^{46}$ The objective of OHADA according to article one of the treaty is the "harmonization of business laws in the contracting states by the elaboration and adoption of simple modern common rules adapted to their economies, by setting up appropriate judicial procedures, and by encouraging arbitration for the settlement of disputes." 47 The scope of business laws to be covered by the uniform acts is defined in article two, but the Council of Ministers is given the power to include any other matters falling within the definition of business laws. 
The institutions of OHADA, after the revision of the treaty in Quebec on 17 October 2008, are:

- The Conference of Heads of State and Government

- The Council of Ministers

- The Permanent Secretariat

- The Common Court of Justice and Arbitration (CCJA)

- The Regional Training Center for Legal Officers

The treaty and the regulations made under it set out the general rules that govern the functioning of the organization.

The Quebec amendment introduced the Conference of Heads of State and Government as the supreme institution of OHADA. It has jurisdiction in all matters relating to the treaty, and its meetings, chaired by the head of state and government whose country chairs the Council of Ministers, are organized at the initiative of its president or at the initiative of two-thirds of the member states.

Despite the Quebec amendment, the Council of Ministers, which must meet at least once a year, plays an important role in the workings of OHADA. It is composed of the ministers of justice and finance of member states, probably to underscore the fact that OHADA is concerned with matters of business law where economic and financial issues are at stake. Perhaps the most significant aspect of the council's role is the functions conferred on it by the OHADA treaty. These are broad and have an administrative and legislative character, including the adoption and amendment of uniform acts, the determination of the area of business law for harmonization, the election of members of the CCJA, and the approval of the annual program of harmonization of business law. The Council of Ministers-not the parliaments of member states-determines the program, the content, and finally the texts of the uniform acts. So far, nine uniform acts have been adopted. ${ }^{48}$ These cover general commercial law, commercial companies and economic interest groups, securities, ${ }^{49}$ simplified recovery procedures and enforcement measures, ${ }^{50}$ collective insolvency proceedings, ${ }^{51}$ arbitration, ${ }^{52}$ accounting law, ${ }^{53}$ the carriage of goods by road, ${ }^{54}$ and cooperatives. ${ }^{55}$

The third institution, the permanent secretariat, acts as the executive body. Headed by a permanent secretary, it mainly functions to assess the main areas where the harmonization of laws is necessary, proposing to the Council of Ministers the annual program of harmonization and coordinating the work of the experts who usually draft the uniform acts. ${ }^{56}$

The CCJA consists of nine judges elected for a nonrenewable period of seven years. ${ }^{57}$ According to article fourteen of the OHADA treaty, the CCJA is required to ensure the uniform interpretation and application of the treaty and the regulations promulgated for its implementation-the uniform acts and other actions. It is primarily vested with judicial and advisory powers and may intervene in arbitration proceedings. The full details of its operations are not relevant for our purposes here. Suffice it to say that in exercising its judicial functions, it acts as the final court of appeal for all 
disputes relating to the interpretation of any laws adopted under the OHADA regime. Its decisions have the force of res judicata in the territory of member states. In its advisory capacity, its advisory opinion may be sought by any contracting party or the Council of Ministers on any matter within the OHADA regime. Where the parties to a dispute opt for arbitration, there are two possibilities: a form of institutional arbitration within the framework of the OHADA treaty, in which the CCJA plays a role in the proceedings, or the option of ad hoc arbitration governed by the Uniform Act on Arbitration Law. Ultimately, the main role of the CCJA with respect to arbitration within the OHADA system is to ensure that the proceedings be orderly and successful.

Finally, the OHADA treaty provides for the Regional Training Center for Legal Officers, which, according to article forty-one, acts as an institution for training, improvement, and research in business law. It operates as a documentation center on legal and judicial matters and is supposed to promote research in the harmonization of business and African laws.

Much has been written about OHADA ${ }^{58}$ and what it has achieved. After seventeen years of its existence, there are still questions whether it provides the best way forward with respect to the harmonization of national laws on business law in Africa. To determine this, it is necessary to undertake a critical review of OHADA.

\section{A Critical Appraisal of OHADA}

Now that it is clear-from global trends in the harmonization of international business laws reviewed above and from which Africa cannot isolate itself-that such a process on the continent is an economic, political, social, and pragmatic imperative, before considering the idea whether OHADA is the way forward or there are other options, it is necessary to look at some of OHADA's main strengths and limitations.

Looking at the Positives Scholars who have studied and written about the OHADA regime point to a number of positive accomplishments. Some of the important accomplishments are worth highlighting here. For a start, it appears to have provided a bridge for bringing the common law and civil law closer together in Africa. ${ }^{59}$ It would, however, be going too far to suggest, as some have done, that it has brought such a convergence between the legal systems that one may no longer consider them "two different and separate legal systems." ${ }^{\prime \prime 0}$

One of OHADA's major goals, stated in its preamble and article one of the treaty, is to make common business laws that are simple, modern, and adaptable to present economic realities. It appears to have accomplished this goal, as some have praised its "clarity and sophistication." ${ }^{\prime 11}$ One, however, has to note Gustav Kalm's conclusion, based on an empirical study, that "whereas OHADA laws have enhanced textual legal certainty, their impact on judicial legal certainty has been small." 62 Given that the regime has 
been fully operational only since 1998, more time may be needed to assess properly whether it has achieved these goals.

OHADA's uniform acts are designed to displace and supersede the national laws of the member states on the subjects concerned, but they do so in a manner that does not necessarily impose any new legal traditions and court systems in member states. ${ }^{63}$ There is some limited built-in flexibility that will ensure that concepts from common law or civil law can coexist with the new framework ${ }^{64}$ and that there can be uniformity only where it is absolutely necessary. ${ }^{65}$

Another advantage of OHADA is that the new uniform laws have not only introduced a single, modern, flexible, and predictable legal framework adapted to the legal and economic system in member countries, but provided an indication of the critical areas in which harmonization is possible and, given a reasonable guide, how this can be done. ${ }^{66}$ One cannot easily forget that until the OHADA uniform framework was developed, most of these countries, a typical example being Cameroon, depended on archaic, uncertain, incoherent, and often contradictory business laws, dating to the colonial period. OHADA has put in place a permanent system for legal modernization that could be more responsive to the practical realities of change than the national systems of making laws.

Finally, an important innovation that lies at the heart of the OHADA system is the CCJA, which provides judicial and arbitral jurisdiction and the Regional Training Centre for Legal Officers. These are designed to ensure that there be high-level legal personnel who can apply the OHADA law in a proper, efficient, and consistent manner among member states and thus sustain uniformity. The CCJA provides the possibility of access to a court system that is likely to be more reliable and efficient and less corrupt than the national courts in member states, which are hamstrung by inefficiency and judicial corruption. Because of the CCJA regime, it has been suggested that transaction costs may fall and potential investors, foreign and domestic, will have greater confidence that their contracts will be respected. ${ }^{67}$

The biggest challenge of OHADA today is to extend its membership to anglophone Africa, ${ }^{68}$ but it has nevertheless laid down the foundation for the eventual emergence of harmonized international business laws uniting all African countries. The prospects for this to happen depend on how it can overcome many of its weaknesses.

Some of OHADA's Limitations There is no doubt that OHADA has made a significant difference in the regulation of commercial matters among its member states; nevertheless, the framework and the regime have weaknesses.

First, there is a question about its legitimacy. This goes not only to how it originated, but also to how it operates and its goals. Influential international institutions and countries were instrumental in the creation of it, but the main actor was France, ${ }^{69}$ which provided not only most of the funds, but also the ideas. It is thus no surprise that the most significant influence on the OHADA acts is French law. ${ }^{70}$ It was inevitable that 
for a start, the OHADA system would be heavily influenced by civil law, but recent laws show that it is opening up to influences from elsewhere. ${ }^{71}$ However, probably to disguise the fact that it was a "top-down French-led reform," 72 a distinguished African legal scholar and former Vice President of the International Court of Justice, the late Judge Keba Mbaye, was given the responsibility of driving the process that led to the establishment of the organization. ${ }^{73}$ The early drafts of the main treaty, as well as the early uniform acts, were prepared in France by French experts, and African partners were required only to comment on the drafts. ${ }^{74}$ In fact, Gustav Kalm has even gone further to say, based on an interview with a francophone lawyer who has worked in France, that the "OHADA business laws were often a word-to-word copy of the French business laws[,] even to the point of including the same grammar mistakes." ${ }^{\prime 75}$ The feeling that OHADA laws are dictated from abroad ${ }^{76}$ still persists and raises serious questions about the real identity and democratic legitimacy of the OHADA regime. National parliaments no longer have the power to make laws dealing with any aspect of business laws, which under the OHADA treaty have been reserved to be regulated by OHADA. Under the treaty, the process of making these uniform acts is led by the Permanent Secretariat and Council of Ministers and member states through their national commissions, which have the opportunity only to review the drafts that have been sent to them. These drafts are prepared by local experts from member states with the assistance of foreign experts..$^{77}$ Thus, the making of laws in these matters is far removed from the population and their elected lawmakers. Claire Moore Dickerson has argued that "the entire OHADA regime was typically adopted by the governments' parliaments[,] ... and to the extent that these are democratically elected, the organs of OHADA can assert at least indirect democratic legitimacy." ${ }^{\prime 78}$ This might well be so, but it does not provide an entirely convincing and satisfactory way of responding to the legitimacy problem, nor does it dispel the suspicion that the OHADA agenda may not necessarily reflect the individual or collective agendas of the member states. It reinforces doubts about whether OHADA was primarily designed to serve their best interests. In fact, there are suggestions that French support for the project was not for purely altruistic and benevolent reasons. It could be inferred from Judge Mbaye's accounts that the French goal was to "progressively transform the CFA zone monetary union into a veritable economic union and one big market," for its companies to trade with. Thus, OHADA's goal—-to encourage foreign investment into the treaty territory-may well be on terms dictated not by its members' interests, but by those who want to bring in the investment. Probably because of this foreign influence on the regime's creation, two critical factors reflective of the African economic reality were ignored or glossed over. One of these is that the regime pays more attention to regulating transactions involving big businesses and multinational corporations than it does to regulating transactions involving smaller businesses or even the informal economy, which is the driving force of African economies in 
the region. ${ }^{80}$ The other is that it does little to promote intra-African trade, which is of fundamental importance to economic recovery and growth on the continent.

Closely linked to the identity problem is the question of whether OHADA was ever intended to expand beyond the francophone world. All the original and subsequent members have legal systems that are based on or closely associated with the French legal system. Both the Spanish system, which operates in Equatorial Guinea, and the Portuguese legal system, which operates in Guinea Bissau, can be traced back to the French legal system. ${ }^{81}$ Except for the language problem, which has now been solved with the amendment of article forty-two of the treaty to include English, Spanish, and Portuguese as OHADA's working languages, ${ }^{82}$ the regime operates among and within states that share a common legal tradition. The only exception is Cameroon, where, though the legal system is predominantly based on French law, English law or remnants of it continue to apply in the two English-speaking regions of the country. In fact, proponents of an easy expansion of the OHADA regime into the rest of Africa, especially anglophone Africa, have tried to use Cameroon as proof that it can easily be adopted in anglophone countries. ${ }^{83}$ Expanding OHADA will require serious efforts to welcome, accommodate, and actually attempt to harmonize laws and not merely transplant French texts. As is shown below, Cameroon, if anything, is a red light, warning of how not to expand OHADA. It is a system that has become too closely identified with a particular legal system and a particular legal mentality. Expanding OHADA will require a fundamental change in attitude and mentality and will depend on whether the present members are ready for such a change.

The establishment of the CCJA to ensure the uniform interpretation and application of the treaty, though one of the strengths of the OHADA system, is a potential source of problems. It is fairly unrealistic to expect that a single supranational court based in one member country will handle all cases dealing with the OHADA regime, given the problems that perennially afflict the administration of justice in Africa: huge case backlogs, the lack of trained judicial staff, and the high cost of litigation, making justice inaccessible to many, especially the poor. This is particularly challenging because the CCJA has been given broad powers to decide all legal questions relating to the interpretation and application of the treaty, the uniform acts, regulations, and decisions, as well as administrative decisions of OHADA institutions and the judicial decisions of the national courts. Parties may even appeal decisions directly to the CCJA, bypassing their national appellate courts. Despite attempts to build flexibility into the CCJA proceedings and reduce costs, this makes a difficult process more complicated. It results in additional time and costs, which the average African business person will find burdensome. It is little comfort that poor litigants do not need to travel to Abidjan because the court can base its decision on written submissions, nor that the court can sit in any country if it deems this necessary. It is therefore no surprise that by 2005 , more than 90 percent of the cases that 
had been heard by the CCJA had come from Ivorian parties ${ }^{84}$ It must not be assumed that exclusive reliance at this critical stage of a dispute only on written submissions will guarantee a fair and just outcome. Perhaps more problematic is the fact that the OHADA regime has so far concentrated mainly on harmonizing rules of substantive law, yet cases can easily be lost or won depending on the rules of procedural law that are followed: the interpretation given to a particular provision may depend on the techniques of statutory interpretation used, and there are not any uniform rules that provide guidance on this. Besides, that the OHADA regime is intimately associated with the French system suggests that any fair and proper interpretation of these laws must have French law as its reference point. This is not a brilliant idea for a system that is supposed to be all-inclusive. Ultimately, while the desire to ensure a uniform and consistent interpretation of the OHADA acts is understandable and commendable, it is doubtful whether this is realistically attainable or even deserves the priority it has been given. It should not just be an obsession with uniformity for its sake, but one that focuses on ensuring a just and reasonably predictable outcome of disputes under the OHADA regime. This can be achieved without having to establish a supranational court that may not realistically be able to handle all the disputes that could arise when the system is functioning at an optimum level in all member states. If the CCJA system has to be retained, then it must be heavily streamlined and decentralized to ensure that ordinary citizens, especially the poor, can have access to justice.

Finally, Cameroon has been put forward as an example of how OHADA can work in anglophone Africa. Many proponents of this view who have commented on the Cameroonian situation have ignored the numerous anomalies it has created or glossed over them. ${ }^{85}$ Three particular problems need to be noted. First, the OHADA regime was imposed on anglophone Cameroonians without warning, consultation, or discussion. English common-law principles of business law were swept aside overnight and replaced with OHADA. Hardly any anglophone scholars, lawyers, or judges were prepared for the dramatic and revolutionary change. As a result, some judges initially refused to apply the OHADA acts ${ }^{86}$ and gave in only under pressure from the Minister of Justice. A senior anglophone judge indicated that "many sitting judges did not know about OHADA until after the first OHADA laws were already in effect," and were "furious and embarrassed to have learned about OHADA for the first time not from the government or from OHADA, but rather from counsel pleading a case. ${ }^{\prime \prime 7}$ OHADA therefore applies in anglophone Cameroon today not because the people directly or indirectly wanted it, but because the government imposed it. So far, there is nothing to suggest that if the people of this region had a choice, they would go for OHADA. Second, the constitutionality of the OHADA regime in Cameroon is questionable. One of the main reasons for this, the virtual imposition of the French language and French texts in a country where the constitution expressly sanctions bilingualism, might have been removed with the amendment of article forty-two of the treaty to make English a working language, 
but there remain many nagging questions. Unfortunately, because individual citizens have no standing to challenge violations of the constitution before the courts, the OHADA constitutional questions will never be tested in court. ${ }^{88}$ Third, anglophone judges have had great difficulties in interpreting Cameroonian harmonized laws drawn largely from French laws in a manner that is consistent with francophone judges, mainly because of the differences in rules of interpretation and other English-law procedural rules used. ${ }^{89}$ It will therefore be even more difficult to expect them to interpret and apply OHADA texts that make little pretense at incorporating commonlaw principles in a manner that will be consistent with interpretations by francophone judges, especially those at the CCJA.

Since it is most unlikely that the OHADA system can be imposed in anglophone Africa the way it was imposed in anglophone Cameroon, and in the light of some of the lessons from there, a different approach must be adopted if the harmonization of business laws in Africa is to be pursued, with or without OHADA leading the way.

\section{Conclusion and the Way Forward}

If the project of harmonizing international business laws in Africa is to succeed, then it must be approached with a sensitivity that takes into account the past, present, and future of the legal systems in place. As the Chinese proverb puts it, "A journey of a thousand miles starts with the first step." The harmonization process in Africa may well be a journey of a thousand miles in which OHADA has taken the important first step. The goal today in Africa must be to expand OHADA in such a way that it will include all the countries on the continent. This presents African politicians and jurists with a tall mountain to climb. A Zimbabwean proverb says, "When there is a mountain in your path, do not sit down at its foot and cry: get up and climb it." Yes, OHADA is a big step in the right direction, and it lays down a good foundation on which the future can be built. It is not perfect, and no successful project of the harmonization of laws ever results in perfect harmony and uniformity. If we have to move forward, then we must again remember the Liberian proverb, "If you go into the forest to look for a perfect stick, you will come out empty-handed." Seven important points must be noted if there is to be progress.

The first is that OHADA has so far succeeded in doing no more than modernizing and unifying disparate national laws from countries operating within the same legal system - the French civil-law system. Contrary to certain optimistic views to the contrary, ${ }^{90}$ the common-law and civil-law systems have not sufficiently overcome their historical differences and converged to such an extent that the harmonization of business laws, if some anglophone countries join the organization, will be easy. To accommodate new members from a different legal culture, OHADA will not only have to reconsider some of the present acts, ${ }^{91}$ but will have to change its approach 
to harmonization to reflect the legal diversity on the continent. It must now strive to undertake genuine harmonization, as the concept has been broadly defined. ${ }^{92}$

Second, the legal diversity on the African continent cannot simply be ignored or wished away. It is a practical fact and aspect of life, and it must be acknowledged, understood, accepted, valued, and celebrated. Properly managing legal diversity through a diversity-conscious approach must be the underlying philosophy of OHADA if it wants to break into anglophone Africa. Such an approach creates space for inclusion, rather than exclusion, on account of differences and requires a conscious effort to look critically at the differences and similarities of legal approaches and see which best meets the expectations of all. The goal in valuing legal diversity is to capitalize on the strengths of each legal system but in an objective and sensible manner, which takes account of the social, economic, and psychological needs of each country and its challenges and strive to find an accommodation of all these. Laws that reflect the diversity of the legal systems on the continent are likely to be a better reflection of a changing world and marketplace, but they will not be easy to formulate or adopt.

A third point, closely linked to the preceding, is that the diversity-conscious approach to harmonization requires flexibility. Some developments at the international level and on other continents have shown not only that the regional harmonization of business laws is possible and imperative, but also how this can be done in a flexible and realistic manner. African countries can learn a lot from the CISG adopted by UNCITRAL, today regarded as one of the most important harmonizing trade instruments..$^{93}$ The important lesson that can be drawn from this effort is that legal harmonization is a long and cumbrous process, even where there is a big need for it, but it can be successfully implemented if the area of law targeted is well chosen and limited and not overambitious. ${ }^{94}$ Perhaps the greatest significance of the UNCITRAL approach to modernization and harmonization is that it combines multiple ways: the use of conventions, model laws, and legal and legislative guides. The main lesson here for OHADA is that it must now be ready to accommodate other legal systems by adopting uniform standards only where necessary and possible but using model laws and legal and legislative guides to be as inclusive as possible. This is necessary to take account of the fact that international business transactions are so multifaceted that it may well require diverse approaches with different emphasis and priorities.

Fourth, a crucial element in harmonization is the ability of legal experts and politicians to overcome their fear of the unknown, be openminded, and be ready to consider legal rules that have worked well elsewhere. The harmonization exercise requires cooperation, understanding, and compromise. The focus must be on the merits of particular principles or rules and their ability to provide a suitable and effective solution to a problem, rather than their provenance from one system or another. There must be a greater drive in Africa to introduce in legal education curricula courses on comparative law and a comparative approach to all legal studies at the 
postgraduate level. There is a need for more institutes and think tanks with a regional and global focus to carry out research in legal harmonization. Only when there is some familiarity or understanding of the law of one jurisdiction can a person from another jurisdiction adjust and adapt to concepts and principles from it without difficulty.

Fifth, while many African countries have had no difficulties ratifying or acceding to treaties, the domestic implementation of these treaties has always been a problem. It can be overcome by making the uniform acts automatically binding and applicable in the territory of member states without the need for enabling legislation, though this raises issues of democratic deficit in the enactment of these laws. Cameroon today provides an excellent example of a country where the harmonization project has enabled it to adopt modern business laws that it would otherwise have found extremely difficult politically to adopt. More generally, such harmonization of laws is usually a relatively inexpensive and effective means of modernizing the law. ${ }^{95}$

Sixth, the recently created AUCIL can speed up the harmonization process in Africa if its mandate is expanded to include the preparation of draft conventions or model laws on business laws for signature by states. It might, however, be better for the African Union to create a separate and specialized body for this purpose. As the example of the European Union shows, regional initiatives, particularly those that have lawmaking mechanisms and organs, such as the AUCIL, have been quite successful in promoting harmonization. If the AUCIL or another African Union body can draft instruments that are accepted and ratified by numerous countries having different legal systems, this will considerably help the process of the integration and harmonization of laws.

Finally, the experiences of other continental legal systems, especially the efforts at harmonizing laws within the European Union, will continue to provide invaluable insights on how to approach these issues in Africa. It must now be realized and accepted in Africa that the harmonization of international business laws in the face of the globalized and liberalized economic situation of today is inevitable. The sooner this is done, the better, because delays will lead to laws adopted by powerful states and powerful regional blocs being imposed on African countries. It must now be recognized and accepted that harmonization of international business laws in Africa is not an issue of one legal system versus another, but what legal principles from any of the different legal systems are most suitable to the different aspects of inter- and intra-African cooperation needed to promote economic recovery, growth, and development.

The harmonization of international business law in Africa should not degenerate into a process of imposition, or even the blind transplantation of foreign laws: it is a process of engagement with modern realities-a reality that shows that insularity at the state level or at the level of historical, linguistic, and cultural blocs is obsolete and will do Africa no good. Artificial 
barriers that have retarded Africa's economic progress must be pulled down. For Africa to be fully integrated into the global economy and lay down a solid foundation for economic recovery and growth, it needs to catch up quickly with the process of harmonization of international business law. OHADA at the moment represents the best effort that has been made. Developments within the African Union and the RECs are a clear indication of an awareness and recognition of the need for a much broader continental approach. The decision whether to proceed by making OHADA more attractive and inclusive or by creating within the African Union a special commission to pursue this goal is a political, not a legal, decision. Though there is no common theory or principle on how to harmonize business laws on a continental level, what emerges from the experiences of other agencies, especially UNCITRAL, is that clarity, flexibility, modernization, fairness, and diversity consciousness in the approach adopted is crucial.

NOTES

1. As Fazio (2007:8) points out, in the globalized and liberalized world economy of today, economic actors may decide where to invest and locate their activities, depending upon conditions such as low labor costs, environmental rules, and rules for settling disputes.

2. The efforts of the European Union are well known. Less well known are the efforts of a regional body such as the Organization of American States, which, unlike the African Union, has sponsored quadrennial conferences on private international law, known as the Inter-American Specialized Conferences on Private International Law, that have resulted in the drafting of several conventions - for example, the Inter-American Convention on Law Applicable to International Contracts of 1994, the Inter-American Convention on the General Rules of Private International Law of 1979 and the Organization of American States Model Law on Secured Transactions.

3. See, for example, Rosett (1984) and Stephan (n.d.). Perhaps one of the most interesting recent papers is Derreira-Snyman and Ferreira (2010), especially at p. 611, where it is asserted that "internationally there seems to be a growing trend to move away from harmonization and instead give greater recognition to legal pluralism as an alternative." The authors proceed to cite at considerable length in several parts of the paper two proponents of this so-called new thinking about legal pluralism: Berman (2007) and Burke-White (2004).

4. For a discussion of its advantages and disadvantages, see Goode (1993) and Wool (1997).

5. L'organisation pour l'harmonisation de droits des affaires en Afrique.

6. See generally Fombad (1991, 1997, 1999).

7. Boodman (1991).

8. But see Kähler (2007), who asserts that the purposes of harmonization of law in Europe is to eliminate differences.

9. Kähler (2007).

10. Goldring (1978).

11. Cuming (1985).

12. Boodman (1991). 
13. Derreira-Snyman and Ferreira (2010). These authors also distinguish harmonization from coordination, which they define (p. 612) as something less than harmonization, a sort of preparatory step in the harmonization process.

14. Block-Lieb and Halliday (2007).

15. Block-Lieb and Halliday (2007:19).

16. See, for, example, Bamodu (1994); Dickerson (2009a, 2009b, n.d.); Mancuso (2008a, 2008b); Martor et al. (2007).

17. For instance, the interpretation of the vaguely worded reception clauses in the laws that provided the basis for the reception in most former British colonies has provoked controversy and debate over the years with respect to the exact quantum and delimiting date of English law that was received. For a full discussion of this, see Allott (1970), Park (1963), and Roberts-Wray (1960). With respect to the debate in Cameroon, see Fombad (1991).

18. Kone (2003) notes that before the signing of the OHADA treaty in 1993, only Senegal, Guinea, and Mali among the OHADA member states had attempted any systematic review of the business laws that they had inherited at independence. See Paquin (n.d.).

19. Standard Bank Economist (n.d.).

20. Standard Bank Economist (n.d.).

21. These are CEN-SAD (the Community of Sahel-Saharan States), the Common Market for Eastern and Southern Africa, the East African Community, the Economic Community of West African States, the Economic Community of Central African States, the Intergovernmental Authority for Development, the Southern African Development Community, and the Union du Magreb Arabe.

22. Christian Science Monitor (2011).

23. See discussions of this by Bamodu (1994) and Ndulo (1996).

24. Kone (2003:10-11).

25. See generally, Fombad $(1991,1997,1999)$.

26. Ajulo (1985).

27. Available at http://www.ohadalegis.com/anglais/firstvisit.htm.

28. See article one of the Charter of the United Nations.

29. For information on UNCITRAL, see generally http://www.uncitral.org/uncitral/en/index.html; Block-Lieb and Halliday (2007).

30. See G.A. res. 2205(XX1), UN GAOR, $21^{\text {st }}$ session, supp. no. 16, UN Doc. A/6594 of 17 December 1966.

31. These are all explained at http://www.uncitral.org/uncitral/en/index.html.

32. Some of the most significant ones are the United Nations Convention on Contracts for the International Sale of Goods of 1980 (Vienna), UNCITRAL Legal Guide on International Countertrade Transactions of 1992, UNCITRAL Arbitration Rules of 1976, UNCITRAL Model Law on International Commercial Arbitration of 1985, and UNCITRAL Model Law on International Credit Transfers of 1992.

33. It was established as an organ of the General Assembly in General Assembly resolution 1995(XIX).

34. See http://www.unctad.org/en/Pages/Home.aspx and http://www.unctad.org/en/Pages/ AboutUs.aspx.

35. See http://www.hcch.net/index_en.php?act=text.display\&tid=4.

36. See http://www.unidroit.org/dynasite.cfm?dsmid=103284.

37. Bamodu (1994); Ndulo (1996). 
38. Fazio (2007:17).

39. For a detailed discussion of this, see Fazio (2007:17-22).

40. See the discussion at Fazio (2007:19-23).

41. Wellens and Brochardt (1989).

42. This is discussed by Faria (n.d.).

43. See the African Union model law on safety in biotechnology at http://www.africa-union.org/ root/au/auc/departments/hrst/biosafety/DOC/level2/Presentation_DraftRevAMLSB.pdf and the African Union model law on rights of local communities, breeders, and access, at http:// www.grain.org/brl/?docid=798\&lawid=2132.

44. Chikin (1989).

45. The treaty entered into force on 18 September 1995 after receiving the minimum number of ratifications required for its entry into force.

46. The other countries are Benin, Burkina Faso, Central African Republic, Congo, Ivory Coast, Gabon, Guinea, Mali, Niger, Senegal, Chad, and Togo. The latest member of OHADA is Democratic Republic of Congo, where the OHADA regime took effect on 12 September 2012.

47. Unless otherwise indicated, all quotations from the OHADA treaty or its uniform acts are taken from the official translations of the original texts available at the English site, http://www .ohadalegis.com/anglais/about_ohada.htm.

48. However, Kalm (n.d.) suggests that there are now ten uniform acts, but no evidence of this could be found, at either the OHADA website or that of the supporters' group, Association pour L'unification de Droit en Afrique. This is not surprising, though, for both sites are hopelessly outdated in many respects.

49. These first three uniform acts were adopted by the Council of Ministers on 17 April 1997 in Cotonou and entered into force on 1 January 1998.

50. Adopted on 10 April 1998 in Libreville, it entered into force on 10 July 1998.

51. Adopted on 10 April 1998 in Libreville, it entered into force on 1 January 1999.

52. Adopted on 11 March 1999 in Ouagadougou, it entered into force on 11 June 1999.

53. Adopted on 23 March 2000 in Yaoundé. The first part of this act, relating to companies' individual accounts, entered into force on 1 January 2001; the second part, relating to consolidated and combined accounts, entered into force on 1 January 2002.

54. Adopted on 22 March 2003 in Yaoundé, it entered into force on 1 January 2004.

55. Adopted on 15 December 2010 at Lome.

56. See articles $6,7,11,29,40$, and 61 of the OHADA treaty.

57. On the CCJA, see generally articles 13-26 and the Rules of Procedure of the CCJA.

58. Besides the literature referred to at the OHADA website at http://www.ohada.com, see AkinOlugbade (2007); Alford (n.d.); Bamodu (1994); Dickerson (2009); Mancuso (2008a, 2008b); Martor et al. (2007).

59. This has already been happening in Cameroon since the reunification of the Anglophone and Francophone regions in 1961. See generally Fombad (1991, 1997, 1999).

60. Mancuso (2008a, 2008b).

61. Dickerson (2009:108).

62. The main problem that the author identifies as the main cause of this is "the pervasiveness of corruption in the judiciary[, which] keeps OHADA law from having more impact" (Dickerson 2009a:3).

63. Martor et al. (2007:17). 
64. It does this through the existence of many nonmandatory provisions in the uniform acts that apply only where the parties to an agreement have not provided for anything to the contrary. See, for example, article 517 of the Uniform Act on Commercial Companies, which specifies that "except as otherwise provided in the articles of association, shareholders' meetings shall be held at the registered office of the company or at any other place on the territory of the member state of the registered office."

65. For example, the uniform acts do not harmonize the administrative and judicial organization of member states, and the provisions relating to criminal liability allow each member state to determine the exact penalties for each offense.

66. The OHADA Council of Ministers has already adopted uniform acts pertaining to general commercial law, corporate law, and rules concerning different types of ventures, laws concerning secured transactions (guarantees and collaterals), debt recovery and enforcement, bankruptcy law, arbitration law, and accounting law. Under article two of the OHADA treaty, labor law, sales law, and ground transportation law are to be harmonized. The Council of Ministers has indicated an intention to pursue additional business regulations in the areas of competition law, intellectual property law, banking law, laws relating to unincorporated forms of business, contract law, and law of evidence.

67. Dickerson (2009).

68. In 2004, the first OHADA conference outside francophone Africa was held in Nigeria; in February 2008, another took place in Accra, Ghana. The theme of the latter conference was to discuss arbitration under OHADA as a byproduct of the civil-law system against the common-law practice in anglophone Africa. See Diongue (n.d.).

69. See Kalm (n.d.:8-12).

70. Dickerson (2009a:6, 11, 22); Kalm (n.d.).

71. See, for example, the draft principles on the law of contract fashioned after the UNIDROIT principles of international commercial contracts. The introductory part makes clear that these principles are designed as a body of general rules of contract law that would find favor with the legal community beyond the legal particularities of each legal system and are tailored to apply in a contemporary international environment. It points out that they espouse solutions common to all systems or borrow from a given system when that system's rules are deemed more suitable. See UNIDROIT (n.d.).

72. OHADA Uniform Acts on contract: explanatory notes to the preliminary draft, p. 11, http:// www.unidroit.org/english/legalcooperation/OHADA\%20explanatory\%20note-e.pdf.

73. Kalm (n.d.:11-12), however, points out that Judge Mbaye was not exactly a new convert to such an idea because he himself had at some stage promoted the idea of the harmonization of business laws in Africa.

74. As a member of the Cameroonian national committee of about fifteen members, we had two French experts who sat through our proceedings as observers, though they frequently intervened to explain one thing or another.

75. Kalm (n.d.:13).

76. As Dickerson (2009a:46) puts it: "the OHADA system is aggressively top-down, and . . . an aggressively Western/Northern legal system."

77. Kalm (n.d.:13) discusses the ongoing revisions of some of the uniform acts financed and managed by the World Bank but executed by OHADA legal professionals with the "expertise and advice of foreign counsellors."

78. Dickerson (2009:96). 
79. Mbaye (2004:5).

80. Kalm (n.d.:3, 8, 23-26).

81. La Porta et al. (1998).

82. The revised article 42 still places the French language in a privileged position, for it ends thus: "In the event of differences among the texts in the various languages, the French version will control." This sentence could have two possible interpretations: first, that when all existing texts are translated and there is a discrepancy, the French text will prevail; second, that as a general rule, where there is a discrepancy among the texts, the French text will prevail. If the latter interpretation is correct, this seems to suggest that the texts will be prepared in French and then translated into the other languages. If this is the case, then it hasn't solved the language problem, whereby the French language appears to be the official and governing language. Besides, given the rather poor translations that have been done so far, as least insofar as the English texts are concerned, one may suggest that it is safer for those who understand some French to rely on the French text than to struggle to make sense out of the English texts.

83. Dickerson asserts, "Cameroon has already demonstrated that Anglophone, common law lawyers can benefit from OHADA" (2009b:110).

84. Dickerson (2009b: footnote 146).

85. See, for example, the otherwise excellent paper by Kalm (n.d.), who fails to say anything about whether or not OHADA has brought legal certainty in the Anglophone regions of Cameroon.

86. See Justice Paul Ayah in Akiangan Fombin Sebastian v. Foto Joseph \& Others, suit no. HCK/3/96 of 6 January 2000.

87. Dickerson (2009b:45).

88. For discussion of the absence of an effective mechanism for constitutional review in Cameroon, see Fombad $(1998,2003)$.

89. Fombad (1991).

90. Mancuso (2008a, 2008b).

91. Dickerson (2009b:108).

92. In fact, a French writer, Leboulanger (1999), has suggested that the French word harmonisation was used for diplomatic reasons and has emphasized that OHADA business laws are truly unified. There is nothing wrong with such a unification of laws, provided it is necessary and proper in the circumstances.

93. Eiselen (2010).

94. Eiselen (2010:106).

95. Stein (1977-1978).

\section{REFERENCES CITED}

Ajulo, S. B. 1985. Law, Language, and International Organization in Africa: The Case of ECOWAS. Journal of African Law 29:1-18.

Akin-Olugbade, Adesegun. 2007. The African Development Bank's Contribution to the Harmonization of Investment Laws in Africa and Prospects for Future Harmonization of such Laws. ASIL Proceedings.

Alford, Duncan. N.d. A Guide to the Harmonization of International Commercial Law. http://www.nyulaw global.org/globalex/Unification_Harmonization.htm. 
Allott, A. 1970. New Essays in African Law. London: Butterworths.

Bamodu, Gbenga. 1994. Transnational Law, Unification, and Harmonization of International Commercial Law in Africa. Journal of African Law 38(2):125-143.

Berman, Paul. 2007. Global Legal Pluralism. Southern California Law Review 80:1155-1163.

Block-Lieb, Susan, and Terence Halliday. 2007. Harmonization and Modernization in UNCITRAL's Legislative Guide on Insolvency Law. Texas International Law Journal 43(3):1-37.

Boodman, Martin. 1991. The Myth of Harmonization of Laws. American Journal of Comparative Law 39:699-724.

Burke-White, William. 2004. International Legal Pluralism. Michigan Journal of International Law 25:963-979.

Chikin, Christine M. 1989. The Challenge of Soft Law: Development and Change in International Law. International and Comparative Law Quarterly 38:859-860.

Christian Science Monitor. 2011. "African Free Trade Zone Planning Is under Way." June 16. http://www .csmonitor.com/World/Africa/2011/0616/African-free-trade-zone-planning-is-under-way.

Cuming, R. C. 1985. Harmonization of Law in Canada: An Overview. In Perspectives on the Harmonization of Law in Canada, edited by R. C. Cuming. Toronto: University of Toronto Press.

Derreira-Snyman, M. P., and G. M. Ferreira. 2010. The Harmonization of Laws within the African Union and the Viability of Legal Pluralism as an Alternative. Journal of Contemporary Roman-Dutch Law 73(4):608-628.

Dickerson, Claire Moore. 2009a. Perspectives on the Future. In Unified Business Laws for Africa:CommonLaw Perspectives on OHADA, edited by Claire Marie Dickerson. London: GMB.

—_ ed. 2009b. Unified Business Laws for Africa: Common-Law Perspectives on OHADA. London: GMB. . N.d. "Harmonizing Business Laws in Africa: OHADA Calls the Tune." http://law.bepress.com/cgi/ viewcontent.cgi?article $=3073 \&$ context $=$ expresso.

Diongue, Aliou. N.d. "Arbitration: OHADA vs Common Law." http://www.lesafriques.com/en/news/ ghana/arbitration-ohada-vs.-common-law.html?ltemid=35?articleid=0050.

Eiselen, Sieg. 2010. Globalization and Harmonization of International Trade Law. In Globalization and Private Law: The Way Forward, edited by Michael Faure and André Van der Walt. Cheltanham: Edward Elgar.

Faria, Jose Angelo Estrella. N.d. "Legal Harmonization through Model Laws: The Experience of the United Nations Commission on International Trade Law (UNCITRAL)." http://www.justice.gov .za/alraesa/conferences/papers/s5_faria2.pdf.

Fazio, Silvia. 2007. The Harmonization of International Commercial Law. The Netherlands: Kluwer Law International.

Fombad, Charles Manga. 1991. The Scope for Uniform National Laws in Cameroon. Journal of Modern African Studies 29:443-456.

1997. An Experiment in Legal Pluralism: The Cameroonian Bi-Jural/Uni-Jural Imbroglio. University of Tasmania Law Review 16:209-234.

1998. The New Cameroonian Constitutional Council in a Comparative Perspective: Progress or Retrogression? Journal of African Law 42:172-186.

1999. Cameroonian Bi-Juralism: Current Challenges and Future Prospects. In Law in Africa: New Perspectives on Origins, Foundations and Transition: Conference Proceedings, South African Society of Legal Historians, edited by Rena Van den Bergh and Gardiol Van Niekerk. Pretoria: UNISA Press.

2003. Cameroon: Constitutional Law. In International Encyclopaedia of Laws: Constitutional Law, edited by Roger Blanpain. The Hague: Kluwer Law International. 
Goldring, John. 1978. Unification and Harmonization of the Rules of Law. Federal Law Review 9:289.

Goode, R. 1993. Reflections on the Harmonization of Commercial Law. In Commercial and Consumer Law: National and International Dimensions, edited by R. Granston and R. Goode. Oxford: Clarendon Press.

Kähler, Lorenz. 2007. Conflict and Compromise in the Harmonization of European Law. In Private Law and the Many Cultures of Europe, edited by Thomas Wihelmsson, Elina Paunio and Annika Pohjolainen. The Hague: Kluwer Law International.

Kalm, Gustav. N.d. "Building Legal Certainty through International Law: OHADA Law in Cameroon." http://www.cics.northwestern.edu/documents/workingpapers/Buffett_11-005_Kalm.pdf.

Kone, Mamadou. 2003. Le Nouveau Droit Commercial des Pays de la Zone OHADA: Comparaisons avec le Droit Français. Paris: LGDJ.

La Porta, Rafeal Florencio Lopez de Silanes, Andrei Shleifer, and Robert Vishny. 1998. Law and Finance. Journal of Political Economy 106:1113-1118.

Leboulanger, Philippe. 1999. L'Arbitrage et L'Harmonisation du Droit des Affaires en Afrique. Révue Arbitrage 3:546-547.

Mancuso, Salvatore. 2008a. "Harmonization of Laws and Convergence between Common-Law and Civil-Law Families: Lessons from the OHADA Experience." Paper presented at the first Maputo International Conference on Regional Integration and SADC Law, Maputo, Mozambique, April 23-25, 2008. http://www.tipmoz.com/library/resources/Oldsite1/Harmonization_of_Laws_ in_SADC_Mancuso.pdf.

2008b. OHADA and the Future Adhesion of Common Law Countries: Is It a Challenge? In Harmonization of International Commercial Laws in Africa and Its Advantage for Chinese Investments in Africa: Proceedings of a Conference Held in Macao on November 27, 2007, edited by Salvatore Mancuso. Macao, University of Macau Institute for Advanced Legal Studies.

Martor, Boris; Pilkington, Nanette; Sellers, David and Thouvenot, Sébastien 2007. Business Law in Africa: OHADA and the Harmonization Process. 2nd ed. London: GMB.

Mbaye, Judge. 2004. L'Histoire et les Objectifs de l'Ohada. Petites Affiches 205:5-15.

Ndulo, Muna. 1996. "The Need for the Harmonization of Trade Laws in the Southern African Development Community (SADC)." Cornell Law Faculty Publications, Paper 60:211-213. http:// scholarship.law.cornell.edu/cgi/viewcontent.cgi?article=1059\&context=facpub.

Park, A. E. W. 1963. The Sources of Nigerian Law. London: Sweet \& Maxwell.

Paquin, Julie. N.d. L'Harmonization du Droit des Affaires en Afrique: Le Project de l'OHADA. http://www .barreau.qc.ca/publications/journal/vol33/no15/ohada.html.

Roberts-Wray, Kenneth. 1960. The Adoption of Imported Law in Africa. Journal of African Law 1:60-71.

Rosett, Arthur. 1984. Critical Reflections on the United Nations Convention on Contracts for the International Sale of Goods. Ohio State Law Journal 45:265-305.

Standard Bank Economist. N.d. "Africa Must Do Business with Itself." http://www.bizcommunity.com/ Article/410/87/61613.html.

Stein, Eric. 1977-1978. Uses, Misuses—and Non [sic] Uses of Comparative Law. Northwestern University Law Review 72:190-210.

Stephan, M. P. N.d. The Futility of Unification and Harmonization in International Commercial Law. University of Virginia School of Law, Legal Studies Working Paper 99-100. http://ssrn.com/ abstract $=169209$.

UNIDROIT. N.d. OHADA Uniform Acts on Contract: Explanatory Notes to the Preliminary Draft. http:// www.unidroit.org/english/legalcooperation/OHADA\%20explanatory\%20note-e.pdf. 
Wellens, K. C., and G. M. Brochardt. 1989. Soft Law in the European Community Law. European Law Review 14: 267-321.

Wool, J. 1997. Rethinking the Notion of Uniformity in the Drafting of International Commercial Law: A Preliminary Proposal for the Development of a Policy-Based Unification Model. Uniform Law Review 1:30-46. 